\title{
PLAC8 Gene
}

National Cancer Institute

\section{Source}

National Cancer Institute. PLAC8 Gene. NCI Thesaurus. Code $C 90305$.

This gene may be involved in the regulation of dendritic cells. 